\title{
Nacionalizam i globalizam u kvalitativnom posredovanju
}

\author{
DOI: $10.5613 /$ rzs.49.3.4 \\ UDK: $327.39: 316.32$ \\ 323.1:327.39 \\ Prethodno priopćenje \\ Primljeno: 13. 10. 2018.
}

\author{
Slobodan VUKIĆEVIĆ \\ Filozofski fakultet, Univerzitet Crne Gore, Crna Gora \\ vukicevic@t-com.me
}

SAŽETAK

Predmet ovog rada je simetrija i asimetrija nacionalizma i globalizma kao kvalitativan društveni odnos determinisan logosnim valentnostima (značaj, značenje i smisao) njihovih strukturnih segmenata. Cilj je otkrivanje simetrijskih i asimetrijskih mreža nacionalizma i globalizma koje prate njihove pozitivne i negativne dimenzije. Nacionalizam je, u osnovi, refleksija nacije i kao takav, sadrži sve bitne protivrečnosti nastajanja i razvoja nacije, njene povijesne i metafizičke kategorijalnosti. Nacionalizam kao cjelovit društveni fenomen, genetički strukturiran, može se sociološki identifikovati i objasniti, jedino kao simetrija njegovih pozitivnih i negativnih komponenti. Ne postoji "čista" nacija u idealno-tipskoj formi, koja reflektuje samo pozitivni nacionalizam, ali ni nacija koja reflektuje samo negativni nacionalizam. Redukovanje nacionalizma samo na njegovu negativnu stranu onemogućava otkrivanje njegove pozitivne strane. Refleksija nacionalizma nužno se odvija u državi, u kojoj pravo građanstva znači zadobijanje novog, višeg nivoa slobode, a to je jedina logika nacije. Nacija, država i građanin su tako, neodvojivi subjekti određene demokratske zajednice. Globalizam nije samorefleksija globalnog, već refleksija identitetskih simetrija pojedinih društava-država, koja obuhvata svestranu razmjenu njihovih fundamentalnih ljudskih vrijednosti i interesa. Centralno pitanje je na kojim kvalitativnim sadržajima se održava vladajuća simetrija globalizma i njena veza sa (ne)promjenjivošću suštine načina proizvodnje društvenog života. Odgovor na ovo pitanje nije moguć, bez identifikovanja simetrijskih mreža nacionalizma i globalizma, i njihovog kvalitativnog posredovanja, u kojem posebno značajnu ulogu ima država. Ovdje je sadržan originalan teorijsko-metodološki pristup u sociološkom razumijevanju simetrične refleksivnosti nacionalizma i globalizma u savremenom društvu. Teorijsko-empirijsko i sociološko imaginativno otkrivanje karaktera simetrije i asimetrije nacionalizma i globalizma, jedino može voditi naučno objektivnom i istovremeno društveno angažovanom znanju.

Ključne riječi: nacija, nacionalizam, globalizam, logosna valentnost, refleksija, društvena simetrija, simetrijske mreže. 


\section{UVOD}

Društveni procesi nacionalizma i globalizma su dva nivoa kultivisanja ljudske prirode i prirode ljudske zajednice. Oba procesa se zasnivaju na protivrečnostima generičnosti ljudske vrste. Generičnost ima neograničenu metafizičku snagu i dejstvo globalnog karaktera, njegovih pozitivnih i negativnih komponenti. Ona je demijurg globalizma kao potencijala ljudskog roda, njegove iskonske potrebe konstituisanja univerzalne društvenosti na nivou konkretnih društvenih zajednica. Ova potreba se konkretizuje u strukturalno-sistemskim determinantama određenog društva-države. Otkrivanje veze između društvene simetrije i strukturalno-sistemske (ne) promjenjivosti određenog društva, odnosa unutrašnjih snaga i mjesta i karaktera odnosa sa drugim društvima, ima naročiti teorijsko-metodološki značaj. U tom kontekstu, predmet ovog rada je simetrija i asimetrija nacionalizma i globalizma kao kvalitativan društveni odnos determinisan logosnim valentnostima (značaj, značenje i smisao) njihovih strukturnih segmenata (Vukićević, 2016a). Cilj je otkrivanje simetrijskih i asimetrijskih mreža nacionalizma i globalizma koje prate kvalitativno posredovanje njihovih pozitivnih i negativnih dimenzija.

\section{TEORIJSKO-METODOLOŠKI PRISTUP}

Zadatak sociološke nauke je, da na bazi teorijskih i empirijskih saznanja i sociološke imaginacije, objektivizira vjerovatnoću uspostavljanja simetrije i asimetrije nacionalizma i globalizma i tako, kao ishod, stvara upotrebljiva naučna znanja. Time se obezbjeđuje predmetna autonomnost, a to znači objektivnost, $s$ jedne strane, a sa druge, jasan cilj - predmetna racionalnost, u domenu angažovanosti sociološke nauke. Znači, centralno pitanje je kako otkrivati simetriju transplanetarne povezanosti globalizma i suštinskih vrijednosti ljudske prirode. To može ići samo na vremensko-prostornoj i kvalitativnoj osnovi organskog vremena, a nikako ne samo na kvantitativnoj. Vrijeme, u kontinuitetu sadrži jedinstvo prošlosti, sadašnjosti i budućnosti, što znači, da ne možemo imati istu budućnost ako su nam prošlost i sadašnjost esencijalno-egzistencijalno različite. Zimbardo smatra da je glavni uzrok sukoba u svijetu danas "to što ljudi imaju različit vremenski fokus. Jedni su ekstremno fokusirani na prošlost, drugi su ekstremno fokusirani na budućnost" (Zimbardo, 2017: 12). Zato, progres društva možemo procjenjivati samo kao proces oslobađanja od dogmatizacije nacionalnog identiteta, na jednoj strani, i unifikacije globalizma na drugoj. Taj proces se finalizuje u vidu interkulturalizma kao kvalitativnog posredovanja nacionalizma i globalizma u obliku proširene sinteze međudržavnih odnosa. $U$ tom smislu Habermas ističe: "patriotizam prema ustavu znači da građani ne usvajaju principe ustava samo u njihovom apstraktnom 
sadržaju, nego konkretno, iz istorijskog konteksta njihove sopstvene nacionalne istorije" (Habermas i Ratzinger, 2006: 22). Ili, Ratzinger, komparirajući sekularnu i religijsku kulturu, konstatuje: "Između ova dva pola postoji različit stepen bliskosti ili napetosti, uzajamna spremnost da se uči ili manje više odlučno odbijanje [...] Šta sledi iz svega toga? Najpre, tako mi izgleda, faktičko nepostojanje univerzalnosti dve velike kulture Zapada, kulture hrišćanske vere kao i kulture sekularne racionalnosti, ma koliko obe, svaka na svoj način, su uticale na to kako će izgledati ceo svet i sve kulture" (Habermas i Ratzinger, 2006: 44-45). [...] Ratzinger nastavlja: "Drugim rečima, racionalna ili etička ili religijska formula sveta, oko koje bi se svi ujedinili i koja bi onda mogla da nosi celinu - ne postoji. Stoga i takozvani svetski etos ostaje apstrakcija" (Habermas i Ratzinger, 2006: 46).

Radi se o afirmisanju teorijsko-metodološkog pristupa sociološkog izučavanja društvenih fenomena, pa i fenomena nacionalizma i globalizma, koji predstavlja osnovu za identifikovanje simetrijskih veza u kojima se nalazi suština društvenih odnosa i procesa. Još bitnije, otkrivanje simetrijskih mreža koje prate ljudsku prirodu i prirodu ljudske zajednice i u okviru toga kako potrebe suprotstavljenih aktera uspostavljaju simetriju (ne)promjenjivosti određenog društva. Na čemu se održava suprotna simetrija savremenog društva: na jednoj strani kriza generičnosti (kriza socijalne pravde, kriza pogleda na svijet, kriza smisla), na drugoj, kapitalizam - pogotovo finansijski, cvjeta; drastičan nivo malog broja bogatih i velikog broja siromašnih u kojem se mijenja samo brojno stanje, ali društveni odnos ostaje isti. Brojevi ne otkrivaju suštinu nepromjenjivosti vladajućeg društvenog odnosa. Nužna posledica: značajno usporavanje kvalitativnog posredovanja nacionalizma i globalizma. Jedino otkrivanjem suštine (kvalitativnih odnosa, a ne kvantitativnih, gradualnih, teritorijalnih) ove simetrije možemo otkriti uzroke njenog nastanka i održavanja. U okviru ove simetrije se mogu otkrivati uzroci vjerovatnoće nastajanja asimetrije. Formulisani teorijsko-metodološki pristup ne ostaje na kritici nacionalizma kao takvog, niti na kritici globalizma kao takvog, već na kritici negativnih refleksija koje oni prozvode za konkretna društva, na jednoj strani, i na drugoj, na afirmaciji pozitivnih uticaja na ukupni društveni razvoj, čime sociološka nauka ispunjava princip objektivnosti i angažovanosti.

Standardni konceptualni okvir društvenih nauka, pa i sociološke nauke, koji se zasniva na metodološkom teritorijalizmu (prostor bez vremena) i metodološkom gradualizmu i kvantofreniji, nema teorijsko-metodološku, pogotovo ne imaginativnu, snagu otkrivanja suštine društvenih fenomena, pa ni fenomena nacionalizma i globalizma.

Svaki društveni fenomen sadrži, ili, uspostavlja se i održava, na simetriji prostorno-vremenskog i kvantitativno-kvalitativnog odnosa, pa i nacionalizam i globalizam. Vremensko izmještanje mjesta iz prostora ne negira značaj prostora u cjelini, 
već samo oblikuje prostor u novoj strukturi i pruža dokaze o vremenu (Vukićević, 2015, 2016c). Struktuiranje prostora vremenskim uticajem (mrežom iskustva i pamćenja, a ne vremenom koje mjeri sat) nije bez uticaja osobenosti prostora i njegove istorije (Moser, 2018). $U$ društvenoj zbilji, prostor i vrijeme se nalaze u neprestanom preplitanju koje se održava na bazi određene simetrije u obliku organskog vremena (organsko-nelinearno-ciklično vrijeme kao čovjekov neprestani odnos sa: drugim ljudima, prirodom, univerzumom). Imajući to u vidu, Giddens upućuje sociologe da polaznu tačku u analizi savremenog društva, treba da usmjere na to kako se "društveni život uređuje u okvirima vremena i prostora - prostornog razdvajanja" umjesto ideje "'društva' kao sistema uokvirenog granicama" (Giddens, 1998: 26). Sociološka identifikacija simetrije kao ravnoteže i nepromjenjivosti uspostavljenog stanja određenih društvenih fenomena i društvenih cjelina u vidu državnih zajednica, nacionalnih zajednica, multikulturalnih zajednica, uzima jedinstvo vremena $\mathrm{i}$ prostora u njihovom kvalitativnom posredovanju. "Radi se o sticanju suvereniteta vremena i očuvanju raznovrsnosti ličnih vremena" (Safranski, 2017: 183; autorov prijevod). To je teorijsko-metodološki pristup koji ima sociološku cjelovitost i suštastvenost adekvatno prirodi društvenih zakonitosti koje izučava, objašnjava, razumijeva, tumači, pogotovo u slučaju složenih društvenih fenomena kao što su nacionalizam i globalizam.

\section{METAFIZIČNOST NACIJE}

Nacija je strukturno konstituisana zajednica slobodne duhovne identifikacije njenih pripadnika na bazi specifičnosti: etno-antropoloških osobenosti, istorije, jezika, kulture, vjere i građanskih prava. Sloboda, kao unutrašnja logika nacije zadobija svoju istinu u građanskim pravima. Ali, u ovom kontekstu, sloboda nije oslobođenje, već razvoj potrebe za slobodom, kao principom pozitivnog modusa života, oslobođeno postojanje. "Da oslobođenje i sloboda nisu isto, da sloboda nije moguća bez oslobođenog bivstvovanja, ali da ona nikad nije samorazumljivi rezultat oslobađanja, da je pojam slobode koji je svojstven oslobađanju nužno isključivo negativne prirode, te da, dakle, čežnja za oslobođenjem nikako nije identična sa voljom za slobodom" (Arendt, 1991: 23). Na djelu je potreba za slobodom kultivisanja vlastitog nacionalnog identiteta na principima građanskog prava unutar svoje nacije i u odnosima sa drugim nacijama. Susretanje nacionalne slobode i građanskih prava neprestano se odvija u društvenim okolnostima određene društvene zajednice. Karakter simetrije, ali i asimetrije, ovog društvenog procesa sociologija objašnjava teorijskim i empirijskim saznanjima i sociološkom imaginacijom.

Duhovna autonomnost prati nacionalnu zajednicu i njene pripadnike u svim prostorima (državnog i transdržavnog karaktera) u kojima se kreću. Andrićeva anali- 
za Bosne pod turskom vladavinom ubjedljivo pokazuje da je "ideja nacionalnog preporoda i oslobođenja ispod turskog jarma" i "tema oslobađanja hrišćana ispod turskog jarma odgovarala nacionalno-političkom raspoloženju", bila ideja vodilja svih naroda Bosne (Srba, Hrvata, Turaka, Jevreja) (Andrić, 2017: 37). Potreba slobode i istorijske okolnosti postojanja nacije nalaze se u simetrijskom, ali i asimetrijskom, odnosu. Na simetrijskim odnosima nacija se konstituiše i održava kao cjelovita zajednica. Asimetrijske komponente predstavljaju izraz neprestanih unutrašnjih protivrečnosti postojanja nacije. Pozitivna korelacija potrebe za slobodom i principa predmetne racionalnosti afirmišu progresivno značenje nacije u razvoju društvenog bića čovjeka i njegove zajednice.

Metafizička kategorijalnost nacije pretpostavlja njenu duhovnu autonomnost, koja ima generički zasnovanu vrijednost i povijesnu slobodu i u tom kontekstu identitetsku profilaciju određenog kolektiviteta i njegovih pripadnika u vidu Marxovog istorijskog totaliteta (šire u Marx i Engels, 1968-1979). Time nacija suštinski napušta determinizam rođenja u kojem je zatvorena etnička, odnosno narodna zajednica. Sloboda metafizičke stvarnosti nacije, nužno podrazumijeva ne samo svoj subjektivitet, već i subjektivitet drugih nacionalnih zajednica, što je još jedan vid nacionalnog oslobađanja od intra i inter etničke zatvorenosti. Ideja nacije, zasnovana na logici slobode, predstavlja teorijsko-metodološku osnovu sociološkog identifikovanja progresivne refleksije nacionalnih zajednica. Redukovanje slobode kao unutrašnje logike nacije predstavlja, negiranje suštine nacije.

\section{NACIONALIZAM I NACIJA}

Nacionalizam je, u etimološkom i semantičkom značenju, refleksija nacije i njene apriorno-ontološke i antropo-gnoseološke, esencijalno-egzistencijalne determiniranosti. Kao takav, nacionalizam sadrži sve bitne protivrečnosti nastajanja i razvoja nacije, njene povijesne i metafizičke kategorijalnosti. Ne postoji "čista" nacija u idealno-tipskoj formi, koja reflektuje samo pozitivni nacionalizam, ali ni nacija koja reflektuje samo negativni nacionalizam.

Nacionalizam, kao refleksija nacije je generički utemeljena ideja i potreba čovjekovog oslobađanja od etičke datosti, determinizma rođenja, socijalne zatvorenosti, robovske podređenosti, političkog i drugih vidova otuđenja, koje su karakterisale narodne zajednice. Ta metafizičnost nacionalizma je prethodnica nastanka nacije (šire u Gellner, 1997) i progresivni demijurg njenog razvitka. Logika nacije zasnovana na slobodi usmjerava razvoj čovjeka i njegove nacionalne zajednice ka vremenitoj "saigri” prošlosti, sadašnjosti i budućnosti (Heidegger, 1985). Sloboda je uvijek na početku u dijalektici prostora (kao sublimat bivstvovanja, a ne teritorijalnost ili transteritorijalnost) i vremena nacionalnih zajednica. Refleksivnost 
se odnosi na neprestani proces međusobnog "propitivanja" nacije i nacionalizma - ireverzibilan uticaj razvoja nacije na nacionalizam i obrnuto nacionalizma na razvoj nacije. Nova saznanja i nove prakse, nacije i nacionalizma, potvrđuju povijesni karakter i jednog i drugog, antidogmatsku refleksiju koja podrazumijeva i "refleksiju o prirodi same refleksije" (Giddens, 1998: 45). Prema tome, nacionalizam je neobjašnjiv u vidu manihejske podjele: kao pozitivan ili negativan društveni proces. Nacionalizam je društveni proces u kojem se neprestano razrješava unutrašnja protivrečnost nacije na relaciji univerzalno-partikularno. Karakter simetrije koji nastaje na toj relaciji u određenim istorijskim okolnostima pojedinih društvenih zajednica, determiniše vrijednosno-moralnu cjelovitost nacionalizma kao društvenog fenomena.

Nacionalizam prati, u kontinuitetu, prostorno-vremenska simetrija pozitivnih i negativnih komponenti refleksivnosti nacije do današnjih dana. U centru je čovjek i kultivisanje generičnosti njegove ljudske prirode. Nacionalna sloboda nije utopistički usmjerena, na totalno ukidanje zla i konačno ostvarenje dobra, već na neprestano prevladavanje postojećeg "dobra i zla”, jer je to u skladu sa ljudskom prirodom i prirodom ljudske zajednice. Postojeće "dobro“ i postojeće "zlo" su u stanju neprestane upitnosti. "Zlo u čoveku i životu ne sme da nas zaplaši - i zlo i dobro samo su skrivenost života i ljudske prirode" (Andrić, 2017: 2). Svaki drugi pristup bi bio zatvaranje ljudske prirode u postojeće granice "dobra" i "zla", ili, konačnog ukidanja dobra ili zla, a to je protiv ljudske prirode. U ljudskoj prirodi se neprestano susreću univerzalno i konkretno. Međutim, hegelovsko konkretno-univerzalno nije "podizanje partikulariteta na nivo opštosti" (Kangrga, 2003: 9). Hegelovsko konkretno-univerzalno ne znači negiranje, ni jednog ni drugog, već njihovo neprestano spajanje u susretu Logosa i Istorije, ili kako konstatuje Kymlicka "nacija znači istorijsku zajednicu, manje ili više institucionalno dovršenu, koja zauzima datu teritoriju i koja ima osobeni jezik i kulturu“ (Kymlicka, 2004: 22). U kontekstu ostvarivanja generičnosti čovjeka i njegove zajednice, na principu slobode, prevladavanje postojećeg "dobra" i "zla" jeste fundmentalna vrijednost nacije, i njene refleksije u nacionalizmu. Nacionalizam, kao refleksija nacije, autonomna je simetrijska mreža bitnih komponenti nacije sa, istovremeno, zatvorenom i otvorenom strukturom. Nacionalizam prati protivrečenosti nacije kroz: njenu oslobodilačku metafiziku, na jednoj, i apsolutizaciju i dogmatizaciju izvornih komponenti nacije, na drugoj strani. Doktrinarno zanemarivanje ove protivrečnosti, u teoriji i praksi - političkih aktivnosti i pokreta, rezultiralo je redukcijom nacionalizma na njegovu negativnu konotaciju afirmacije sile-agresije i time totalno zatiranje njegove pozitivne strane kao oslobađajuće komponente nacije. U nacionalizmu se susreću dva osnovna smjera: jedan koji prati osnovnu logiku nacije u oslobađanju čovjeka i njegove zajednice od datosti rođenja, i drugi, koji djeluje protiv logosa nacije i dogamtizuje sve bitne 
oslobodilačke komponente nacije, "ruši" metafiziku nacije. Nacionalizam kao cjelovit društveni fenomen, genetički struktuiran, može se sociološki identifikovati i objasniti, jedino kao simetrija njegovih pozitivnih i negativnih komponenti. Centralna sila simetrije nacionalizma se gradi na simetrijskoj mreži odnosa strukturno-sistemskih elemenata nacije i nacionalizma kao autonomnog društvenog fenomena u kojem elementi nacije dobijaju specifičan značaj, značenje i smisao. Znači, nacionalizam se ne može objasniti samo strukturnim elementima nacije, bez njihove veze sa strukturno-sistemskim elementima određenog društva. $U$ toj vezi strukturni elementi nacije dobijaju punu logosnu valentnost koja apsolutno determiniše nacionalizam kao društveni fenomen. Prema tome, nacionalizam je u osnovi refleksija nacije, ali i karaktera strukturalno-simetrijskog identiteta određenog društva.

$U$ tome se izražava genetička struktuiranost nacionalizma koji svojom autonomijom djeluje na stabilnost, održavanje simetrije, ili proizvodi i asimetričnost, nestabilnost i promjene postojećeg načina proizvodnje društvenog života. Protivrečnost nastanka i razvoja nacije reflektuje nužno simetriju suprotnosti pozitivnog i negativnog nacionalizma.

Pozitivni smjer dinamike nacije i nacionalizma rezultira nacionalizovanim građaninom, čija je izvornost nacionalnog identiteta obogaćena ontologičnošću generičke smislenosti. Šta znači stanovište, da je nacionalizam "pre svega paranoja! Kolektivna i pojedinačna paranoja! Nacionalista je po pravilu, kao društveno biće, i kao pojedinac, podjednako ništavan izvan ovog opredeljenja, on je nula" (Kiš, 2016.) Za Kangrgu, nacionalista je ne-čovjek: "odgovor našeg Edipa mogao bi biti samo jedan: to je Hrvat, Srbin, Slovenac, Musliman Albanac, Makedonac [...] To je pravi i jedini odgovor našeg - ne čovjeka, naravno - nacionaliste" (Kangrga, 2003: 8). Znači li to, da pojedinac ne može pripadati naciji, a da ne bude ništavan kao pojedinac, kao društveno biće, kao čovjek, ili, upravo pripadnost naciji predstavlja obogaćivanje slobode pojedinca, njegovo kultivisanje, razvojnu komponentu njegovog društvenog bića, a to znači i razvoj kao pojedinca, kao čovjeka. Prema tome, nacionalizam se može u cjelini objasniti samo u simetričnosti sa nacionalnom slobodom, koja nosi u sebi, istovremeno, i svijetlu (afirmacija slobode) i tamnu stranu (afirmacija sile) istorije. Nacija nije tamna strana istorije, pa ne može reflektovati samo negativni nacionalizam u vidu blokiranja suštine naciona, ideološkom moći političke elite u cilju dugotrajnog održavanja na vlasti, tj. držanja nacije u stanju u kojem ona guši vlastitu slobodu i ostvarivanje vlastitih vrijednosti.

Ako ističemo samo negativnu/tamnu stranu nacionalizma, neizostavan rezultat će biti jačanje nacionalizma kao negativiteta i blokiranje afirmacije njegove pozitivne/svijetle strane. Treba afirmisati pozitivnu/svijetlu stranu nacionalizma, da bi razotkrili/osvijetlili njegovu tamnu stranu sa ciljem njenog prevladavanja. Treba otkriti karakter simetrije strukturne cjeline nacionalizma: svijetle i tamne strane sa ciljem 
njene promjene na principu pozitivne negacije negacije. To je naročito značajno danas kada u svijetu prevladava tip multinacionalnih država koje se mogu održavati jedino na pozitivnim/svijetlim stranama nacionalizma u njegovoj interkulturalnoj formi kvalitativnog posredovanja svih strukturalno-sistemskih komponenti. Suprotna simetrija pozitivnog i negativnog nacionalizma, granični susret, formira se na liniji slobode i sile. To je unutrašnja suprotnost refleksije nacije kao metafizičke oslobodilačke kategorije čovjeka i njegove zajednice u horizontu ostvarivanja njihove generičnosti. Prema tome, svijetla strana nacionalizma je refleksija ljudskog i humanog kvaliteta nacije i njenog prihvatanja multikulturalizma kao interkulturalnog vida vlastite autonomije i širenja vlastite slobode. Tamna strana nacionalizma je refleksija protivrečnosti nacionalnog kultivisanja čovjeka i njegove zajednice koji uslovljava obrnuti smjer negacije negacije, znači afirmaciju negativnih faktora ljudske prirode i prirode ljudske zajednice. Tamna strana nacionalizma nužno prelazi u agresivni nacionalizam, fašizam, šovinizam, rasizam, fundamentalizam i slično. To je crna tačka nacionalizma koja ne dopušta prodiranje sa strane nikakvog svijetla slobode. To je izraz protivrečnog razvoja nacije u vidu gušenja slobode nacije od strane same nacije. $U$ tom smislu Kymlicka ističe da su nakon Hladnog rata, "etno-kulturni konflikti postali najveći izvor političkog nasilja u svijetu" (Kymlicka, 2004: 67).

To upravo upućuje na snažan otpor, teorijski i praktični, redukovanju nacionalizma samo na njegovu tamnu stranu. Na toj tezi je izgrađen poseban vid unutrašnjeg negativnog nacionalizma, semantički označen pojmom "bivša braća". Unutrašnji nacionalizam, "bivša braća", ne priznaje fundamentalnu činjenicu da je svaki narod subjekt istorije koji u specifičnim društvenim okolnostima kultiviše svoju etničku datost i tako formira svoj nacionalni identitet. "Pećinski čovjek i neadnertalac još uvijek su pozvani da nas podsjećaju na to gdje bismo bili bez religije, vlade i truda" (Zerzan, 2012).

Novi nacionalni identiteti, prirodno, najveću opasnost osjećaju od monopola etničkog karaktera naroda i njegovih hegemonističkih nastojanja za potiranje njihove nacionalne slobode. Imajući u vidu primjer srpskog naroda, Vuk Karadžić se pita: "Drugi narodi različitog zakona žive kao braća. Ja ću gledati eda li bi se mogli naći uzroci, zašto je kod nas mimo ostale narode, mogla u ovom događaju postati ovaka mrzost, da narod i na ime svoje omrzne" (Karadžić, 1957: 340). U nacionalizmu "bivša braća", javlja se žal što istorija nije tekla u smislu dogmatizacije etničke datosti naroda. Ustvari, žal što istorija nije blokirala evoluciju, fokusirala vrijeme na prošlost (pretke, istoriju, na stara vremena, sve što je bilo, i to onu "prošlost okamenjenu u njihovom vidnom polju") podređujući joj i sadašnjost i budućnost. Zato, svi pripadnici određenih naroda koji su se uključili u proces kultivisanja i na principu životne organizovanosti obogatili svoju kulturu, jezik, religiju, običaje, svi- 
jest, novim vrijednostima i tako stekli poseban nacionalni identitet su "bivša braća". Radi se, očigledno, o negiranju nužne dinamike evolucije društvenih procesa, a time zakona determinizma i indeterminizma u društvenom razvoju društva uopšte, određenosti i neodređenosti, uzročnosti i slučajnosti. Zamislimo, kakva je retrogradnost ove ideje u odnosu na useljenička društva, kojim bi bilo zabranjeno da u novim društvenim okolnostima grade nove identitete.

Činjenica je, što recimo, svi pripadnici južnoslovenskih naroda nijesu ostali u determinizmu rođenja etničke datosti, već su u datim društvenoistorijskim okolnostima, u koje ih je doveo neki "besporedak" - skup asimetričnih komponenti astrukturalnog karaktera koje zajednički djeluju u smjeru promjene postojećeg poretka, prihvatili nove vrijednosti, postali su "bivša braća" u negativnom kontekstu nacionalizma. Nalaze se pod moralnom osudom što su prihvatili nužnost životnih principa, što su odbacili dogmatizam determinizma rođenja i to najčešće iz elementrane nužnosti opstanka, što su se povinovali lucidnoj Njegoševoj konstataciji da "svi ovi besporeci, po poredku nekome sleduju" (Petrović Njegoš, 1995: 128). Konkretno: dva bliska rođaka od kojih se jedan "igrom slučaja" sa porodicom odselio iz Crne Gore u Srbiju, a drugi, takođe "igrom slučaja”, ostao u Crnoj Gori, razgovaraju: ovaj koji je odrastao u Srbiji upućuje primjedbu rođaku koji je odrastao u Crnoj Gori zašto se identifikuje kao Crnogorac, ne kao Srbin, a on njemu, zašto se "posrbio" i identifikuje se kao Srbin, a nije "ostao" Crnogorac, a pozivaju se na Njegoša, i jedan i drugi. Za Njegoša su, i jedan i drugi, normalna posledica društvenog razvitka, susreta Logosa i Istorije, koji nužno podliježe zakonima uzročnosti i zakonima slučajnosti, determinizma i indeterminizma, u kojima "svi ovi besporeci po poredku nekome sleduju” (Petrović Njegoš, 1995: 128). Pitanje je samo kad će, i jedan i drugi, shvatiti Njegoša, koji jednako poštuje slobodu i dostojanstvo, svakog Crnogorca i svakog Srbina u njihovom vremenskom, a ne samo prostornom određenju. Nacionalizam u socijalističkoj Jugoslaviji bratstva i jedinstva (1945. 1990.), u smislu potrebe za afirmisanjem pojedinih naroda na bazi specifičnosti: etno-antropoloških osobenosti, istorije, jezika, kulture, vjere i građanskih prava, bio je prisutan (Jugoslavija nije bila useljeničko društvo, već su je činili stari istorijski narodi sa svojim identitetima) i prije raspada ove zemlje, ali ga je prikrivala sila simetrije ideološko-političkog monopola. Nacionalni identiteti, posebno nekih zajednica, bili su pod snažnim pritiskom ideološke floskule bratstva i jedinstva koja nije omogućavala adekvatan ireverzibilni proces razvoja metafizičke kategorijalnosti "nacija" multinacionalnog jugoslovenskog društva, već je blokirana utopističkom fikcijom stvaranja jugoslovenske nacije. Jugoslovensku naciju, danas, više niko ne pominje. To je bila identitetska-prisilna simetrija, koja je etničku datost $i$ determinizam rođenja, dogmatizovala i uzrokovala dogmatizovanu refleksiju nacije i nacionalizma, koja je onemogućavala pravovremeno otkrivanje bitnih komponenti 
unutrašnje asimetrije ove refleksije. Faktor ideološko-političke floskule bratstva i jedinstva, iako je sadržavao formulu samoopredjeljenja, blokirao je identitetsku simetriju: a) na republičkom nivou; b) na jugoslovenskom nivou, ističući primarnost bratstva i jedinstva, a to znači stvaranja jugoslovenske nacije, a ne interkulturalnost afirmisanih nacionalnih identiteta multinacionalne strukture jugoslovenskog društva. Kada je ideološko-politički oklop postojeće identitetske simetrije raskinut, na scenu su stupile "zakašnjele nacije" u vidu etničkog determinizma rođenja, dogmatizovani elementi nacije i nacionalizma (krv i tlo). Jugoslavija se našla pred izborom: a) mirnog razlaza (predlog JUS-a - Jugoslovenskog udruženja sociologa da se referendumom odluči o daljoj sudbini Jugoslavije); ili, b) ratnim sukobima (na što je presudno uticala politička elita).

Još uvijek se, u razrješavanju sukoba na jugoslovenskom prostoru polazi od pogrešne pretpostavke da se radi o etničkim zajednicama, zatvorenim u datosti rođenja. Time se potreba slobode nacionalnog identiteta, redukuje na etničko, umjesto da se temelji na građanskom biću zajednice i njenih članova (ova pogrešna pretpostavka je veoma očigledna na primjeru $\mathrm{BiH}$ gdje se i danas, rješavanje sukoba traži u disoluciji tri etničke zajednice u razmjeri 1:1:1). Perspektive nema u etničkoj zatvorenosti. Sam pojam etničke nacije je protivrečan, jer etnička skupina sama za sebe ne može postati nacija. Prema tome, postoji jedna jedina ideja nacije (Schnapper, 1996: 28). Nacionalni identitet u kontekstu građanskih sloboda, ima unutrašnju i spoljnu refleksivnost koja afirmiše vlastiti subjektivitet i subjektivitet drugih nacionalnih zajednica. "Baš napor odvajanja od identiteta i prirodnosti putem apstraktnosti prava građanstva, svojstvo je kojim se odlikuje nacionalni projekat" (Schnapper, 1996: 28). Progres je u nacionalnom, a ne u etničkom identitetu. Nacionalni identitet je osnova "ontološke sigurnosti" svih građana savremenih multinacionalnih država. U tim uslovima formula "bratstvo-jedinstvo" može funkcionistati kao simetrija interkulturalne postojanosti multinacionalne strukture društva.

\section{DRŽAVA I NACIJA}

Nacija u spoju sa državom mora imati kao konstruktivno-regulacionim sredstvom svoje prostorne i vremenske organizovanosti. Istorija kao subjekt prostorno-vremenskog spoja više nacija proizvodi državu kao zajedničko sredstvo više nacija - multinacionalnu državu. Osnovna funkcija države jeste obezbeđenje "ontološke sigurnosti" svih pripadnika nacije ili nacija, kao zajednice slobodnih građana i kao faktor globalne veze konkretnih društava-država. Država koja ne funkcioniše na ovom principu, prije ili kasnije, mora se raspasti. Svi sadržaji nacionalnog identiteta dobijaju logosnu valentnost na bazi koje se povezuju i grade cjelovitost nacije kao zajednice. U novim okolnostima funkcionišu na nov način u skladu sa potrebom 
nove zajednice, njenog mjesta na globalnom planu. U novim okolnostima funkcionišu na nov način u skladu sa potrebom nove zajednice, njenog mjesta na globalnom planu. Svi ti elementi, svoju univerzalnost, ispoljavaju sada tako da postaju aktivni sudionici izgradnje jedne nove opštosti, odnosno simetrijske mreže identiteta nacionalne zajednice. Ako nacija kao transcendentnost etniciteta guši etnokulturni identitet ona postaje fikcija, preciznije rečeno politička fikcija kako kaže Mario Vargas Llosa "u isti mah tiranska i nedjelotvorna, koja je poslužila kao izgovor za najgore zloupotrebe vlasti u XX veku" (prema Schnapper, 1996: 10). Takođe, simetrijska mreža nacionalne zajednice, bez veze na globalnom planu, postaje fikcija.

U simetriji nacionalnog i globalnog, građansko dobija svoj puni smisao. Nacionalni identitet dobija širi prostor generičkog ostvarivanja čovjeka i njegove zajednice. Time multikulturalnost gubi karakter života pojedinih nacionalnih zajednica, jednih pored drugih, a aktivira se interkulturalna povezanost lokalnih kultura i kultura na globalnom planu. To je process u kojem pravo građanstva prevladava svoju apstraktnost, na jednoj strani, a na drugoj, siguran je put transcendiranja etničke zatvorenosti i determinizma rođenja. Građansko se na ovaj način ispoljava kao sloboda ostvarivanja generičke nužnosti čovjeka i njegove zajednice.

Pravo građanstva nije samo slobodna volja nego i prinuda, ono oslobađa, ali i prinuđuje. Pravo građanstva transcendira prirodni determinizam rođenja i tako postaje sloboda, jer čovjek nije više determinisan etničkim datostima, već se konkretno ostvaruje u datoj situaciji koristeći se i etničkim datostima. Prinuda prava građanstva je politizovana nadgradnja prirodnog determinizma. Politički determinizam kroz političku organizaciju daje "značenje obeležjima za koja se veli da su objektivna" (Schnapper, 1996: 68). Objektivnost je fundamentalno definisana sa državom u kojoj pojedinac i kolektivitet ostvaruju svoju nacionalnu slobodu. Tako možemo govoriti o socijalnom, etničkom, kulturnom, istorijskom, religijskom, običajnom i drugim pravima građanstva iz domena "ontološke sigurnosti" ljudi, njihove materijalno-predmetne stabilnosti i očuvanja etnokulturnog identiteta (Vukićević, 2003).

Nesporna je činjenica, da se nacija ne može izgraditi samo na građanskom momentu i zbog toga ona kao istorijska kategorija nije postala univerzalni oblik političke organizacije u vidu svjetskog društva. "Nacionalna država nikad nije uspjela da na isključiv način mobiliše populacije oko nekog specifično političkog projekta, niti da do kraja nametne ponašanje skopčano s prednošću vrednosti građanina nad vezama zajedništva" (Schnapper, 1996: 153). Uostalom, to bi bilo blokiranje same logike nacije. Logika nacije daje prednost onome što se razvija, a razvoj je nezamisliv bez neposrednog spoja Logosa i Istorije. Idealni tip nacije je samo teorijsko-metodološka osnova za otkrivanje simetrija pozitivnih i negativnih aspekata nacionalizma (levičarskog i desničarskog, Forcades, 2017:79) koje nastaju u poje- 
dinim fazama i oblicima susreta Logosa i Istorije. Ovdje apstrahujemo sociološku činjenicu: svako udruživanje ima dva realiteta u značenju i značaju te smislu: a) udruživanje sa stanovišta društvenih odnosa i institucija i b) udruživanje u generičkom smislu.

Nacija, država i građanin su tako neodvojivi subjekti određene demokratske zajednice. Pravo građanstva znači zadobijanje novog, višeg nivoa slobode, a to je jedina logika nacije. U tom kontekstu, patriota je lojalan državi u kojoj ostvaruje svoju "ontološku sigurnost", a time i potencijalni kosmopolit, a patriotizam predmetni racionalizam kosmopolitizma i istinska veza sa pozitivnim komponentama nacionalizma. Nacionalitet i patriotizam su suštinske komponente čovjekove savremene zajednice, kao čovjekove svojine, koja omogućuje njegovo postojanje i ostvarivanje njegove "ontološke sigurnosti" i vlastitosti.

Time je određena matičnost države, koja logički isključuje matičnost bilo koje druge države, ali isključuje i totalno poistovjećivanje nacionalnog i državnog (poklapanje kulturnog i političkog) (Vukićević, 2003). Svaka nacija ili nacionalna manjina, "ontološku sigurnost" nacionalnog identiteta obezbeđuje u određenoj državi, što znači, besmislena je diferencijacija: matična i nematična država. "Srbi iz dijaspore koji neguju idealističku predstavu o 'matici', vezujući je za neku vrstu 'autentičnosti', 'tradicije', i sopstvenih romantičarskih i nostalgičnih sećanja. Ideja o 'matici' ostaje opet izvan vremena, aistorijska, nedotiče tlo realnosti u kojoj velika većina ljudi u Srbiji živi" (Blagojević-Hjuson, 2017). Očigledno "matična" i "nematična država" je aistorijska klasifikacija, a time i izvor unutrašnjeg i spoljnjeg razdora, kako sa stanovišta države na koju se matičnost odnosi, tako i sa stanovišta države u kojoj određeni građani žive.

Zato i pokušaji "matične države" da separatnim "Deklaracijama" štiti nacionalne interese "svoje" nacije u drugim "nematičnim", dovodeći u pitanje njihov suverenitet, sadrže opasnost izazivanja međudržavnih sukoba i ignorišu međunarodno pravo. Pitanja: jezika, kulture, istorije, tradicije, geografije, nasleđa, informisanja, neotuđiva su prava svake autonomne države (pogotovo multinacionalne) čije rješavanje ne može preuzeti ni jedna druga država. Pogotovo ne može preuzeti pravo stvaranja "akcionog plana" u cilju definisanja konkretnih mjera za njegovo realizovanje i finansiranje. Zamislite, šta bi ostalo od Švajcarske kad bi Njemačka, Francuska, Italija i Retoromani propisale posebne Deklaracije o unutrašnjem uređenju Švajcarske (jezika, kulture, istorije, tradicije, geografije, nasleđa, informisanja) sa mjerama za njihove realizacije? Ili je bolje, da se zamislimo nad tim: kako se nacionalni identiteti Nijemaca, Francuza, Italijana, čak i Retoromana kojih je svega $0.7 \%$ u Švajcarskoj, održavaju u punoj "ontološkoj sigurnosti” bez ikakvih spoljnih Deklaracija tkz. "matičnih država"? Ono što Švajcarska jeste "da se politički funkcionirajuća i privredno prosperirajuća državnost, ni u kom slučaju ne mora graditi 
na kulturnoj i jezičkoj homogenosti" (Altermatt, 1997, 99). To je sasvim dovoljna pretpostavka za punu saradnju nacije sa svojim nacionalnim manjinama koje žive u drugim državama i tamo ostvaruju svoju "ontološku sigurnost". Bez obzira na to što je u nastajanju nacije u nekim slučajevima, država odigrala prethodničku ulogu, a u nekim primarnu ulogu su imali kulturološki faktori, postoji jedna jedina logika nacije: transcendiranje etničke datosti "proizvodnjom" građanina i političke organizacije u formi države koja njemu odgovara i koja mora imati značenje matične države. "Danas je svako suštinsko pitanje vezano za određenu oblast - bilo da je riječ o zdravstvu, dokolici, migracijama ili ratovanju. [...] Analogno tome, da bi se postiglo dobro društvo u ovom sve globalnijem svijetu, državna zajednica mora biti rekonstruisana na postteritorijalistički način, prema kojem građanska prava i odgovornosti zahtijevaju supradržavne, kao i državno uslovljene kvalitete" (Scholte, 2009: 424). Očigledna nužnost spoja: univerzalno-konkretno, što znači da država nije istrošena, već se samo radi o njenoj adaptaciji globalnom svijetu, na jednoj strani, a na drugoj, adaptaciji konkretnim okolnostima svake države i njenih građana. Sve je drugo utopizam i dogmatizam protiv prirode čovjeka i njegove zajednice i njihovog postojanja u vremenu i prostoru.

\section{DVOSTRUKI KARAKTER GLOBALIZMA}

Globalizam nije samorefleksija globalnog koja odsijava na unificiranoj poljani svjetskog društva i tabula rasa motivaciono-kognitivnog lika svjetskog čovjeka. Globalizam proističe iz vremenom kultivisane apriorno-ontološke osnove čovjeka i povijesno se ostvaruje na nivou konkretnih ljudskih zajednica. U okviru globalne simetrijske mreže, svaki čovjek i svaka zajednica bivstvuju na bazi sopstvenog simetrijskog identiteta. U osnovi globalizma je društveni proces globalizacije. Globalizacija je poseban nivo društvene apstraktnosti koji ima svoju konstruktivnu i regulatornu dimenziju u vidu međudržavnih - društvenih odnosa savremenog društva, ali nema formu (svjetske) države. Globalizacija obuhvata društvene odnose u najširem smislu, ne samo ekonomske, već i društvene odnose u sferi politike, kulture, morala, religije, tradicije, estetske i moralne svijesti, građanskih prava, itd. Globalizacija je jedinstveni proces unutrašnje i spoljne transformacije na svim nivoima društvene apstrakcije: univerzalnom, društvenosistemskom, konkretnih društava-država, do nivoa svakidašnjeg života i njegove, individualne i kolektivne, estetske i moralne svijesti. Društveni proces globalizacije se efektuira kao globalizam koji ima dvostruki karakter: a) karakter objedinjavanja fundamentalnih ljudskih vrijednosti na principu slobodnog usmjeravanja ka ostvarivanju generičnosti čovjeka i njegove zajednice; b) monopolsko, agresivno nametanje tuđih vrijednosti određenim društvima i pojedincima. Prema tome, globalizam se nalazi u simetriji, ali i asimetriji, ova dva momenta. 
Oba aspekta globalizma uslovljena su karakterom identitetske simetrijske mreže konkretnih društava i njihovim međusobnim odnosima. Globalizam, znači, nije samorefleksija globalnog, već refleksija identitetskih simetrija pojedinih društava, koja obuhvata svestranu razmjenu njihovih fundamentalnih ljudskih vrijednosti i interesa, ali i njihov monopolski izraz ekonomske, tehničko-tehnološke, kulturne i političke moći i interesa. Otkrivanjem karaktera identitetske simetrije konkretnih društava, konstituisanih kao strukturno-sistemski determinisan način proizvodnje društvenog života u određenoj državi, otkrivamo suštinske osnove i refleksivni karakter globalizma, kako njegove pozitivne, tako i njegove negativne komponente. Globalizam je, prema tome, posledica međuzavisnosti konkretnih društava, sa svim protivrečnostima koje ta društva nose sa sobom. U procesu globalizacije diferenciraju se društva koja imaju presudan uticaj (ekonomski, tehnološki, kulturni, politički - moćnija društva) i društva koja više karakteriše pasivna pozicija primaoca uticaja moćnijih društava. Na toj osnovi se uspostavlja globalizacijska simetrijska mreža savremenog društva. Jedino otkrivanjem ove simetrije možemo objasniti karakter globalizma u savremenom društvu.

Ova simetrija se uspostavlja na kvalitativnim odnosima logosnih valentnosti strukturalno-sistemskih elemenata konkretnih društava, a ne samo na njihovim kvantitativno-gradivnim izrazima. Na toj osnovi se odvija neprestani odnos globalizma i glokalizma, tako da je nemoguće objasniti jednog bez drugog. U odnosu globalizma i glokalizma odvija se specifičan circulus vitiosus, vrijednosti konkretnih društava dobijaju opšti značaj na globalnom nivou, ali njihovo opšte značenje doživljava posebnu transformaciju na lokalnom nivou, kao "delanje društvenih aktera u konkretnim lokalnim uslovima" (Petrović, 2012: 9).

Savremeni globalizam značajno karakteriše simetričnost obrnute negacija-negacije, u kojoj primarno mjesto dobijaju monopolske komponente kapitala. Monopol kapitala, prije svega finansijskog, u centru je interesa, a ne fundamentalne potrebe ljudi. Tako i osnovni princip kapitala, proizvodnja novih vrijednosti, gubi na značaju. Centralno je pitanje: na čemu se održava naznačena simetrija globalizma i njena veza sa nepromjenjivošću suštine načina proizvodnje društvenog života (Piketty, 2015; Vukićević, 2016b).

Podjela na globalizam, antiglobalizam, alterglobalizam je neprihvatljiva teorijsko-metodološka pozicija, jer se suština globalizma može objasniti samo u identifikovanju globalizma kao cjelovitog društvenog fenomena sa svim njegovim protivrečnostima, pozitivnim i negativnim komponentama, ispoljenim u odnosu identitetskih simetrija konkretnih društava. Komponente simetrije diferenciraju se na: a) predmetu globalizacije (prirodnim resursima; ljudskoj prirodi i ljudskim resursima; radu - tržištu rada, cijeni rada, uslovima rada; kapitalu - finansijskom kapitalu, tehnici i tehnologiji, investicionom kapitalu); b) subjektima globalizacije (pojedinac, 
država, elite, institucije i organizacije na svim nivoima (konstruktivno - regulatorni sistem).

Znači, osnova globalizma mora biti identitetska simetrija sa subjekatskom autonomijom pojedinca-građanina i države, i njihova pozicija u kontekstu simetričke mreže na svjetskom nivou. Globalizam mora imati specifičnu vezu sa svim identitetskim simetrijama posebnih država koja se uspostavlja na principu hegelovskog konkretno-univerzalno. Znači, globalizam ne može dobiti formu konstituisanog državnog subjektiviteta jer nema svjetskog čovjeka, niti konstruktivno-regulatorno objektiviziranog svjetskog društva, sa svim elementima državnosti, kao nužnih nosilaca tog subjektiviteta (ni jedna država ne prepušta svoj suverenitet ni jednoj međunarodnoj organizaciji, pa ni UN). Globalizam ostaje u formi apstraktne veze identitetičkih simetrija konkretnih državnih zajednica, pri čemu se obezbeđuje postignuti nivo "ontološke sigurnosti" konkretnih društava na nivou pojedinca i kolektivnom nivou društva.

$\mathrm{Na}$ toj osnovi se mogu pratiti pozitivne (simetrične) i negativne (asimetrične) komponente globalizma u njegovoj nelinearnoj-uzročno-posledičnoj, predmetnoj i subjekatskoj determiniranosti. U kontekstu "ontološke sigurnosti" sadržano je centralno pitanje: da li smjer globalizacije ide ciklično od ekonomske nejednakosti ka društvenom blagostanju. Šire pitanje: da li smjer globalizacije ide ciklično od opšte nejednakosti ljudi i društava ka društvenom blagostanju? Konačno: da li se savremeno društvo konstituiše isključivo kao DNP (društvo nacionalnog proizvoda) ili kao DNS (društvo nacionalne sreće)? Razlike bogatih i siromašnih se ne smanjuju, znači globalizacija ne ide u smjeru od društvenih nejednakosti ka društvenom blagostanju. To je evidentna nepromjenjivost ljudskog društva na globalnom i na posebnom nivou. U okviru nje dolazi do kvantitativnih promjena, ali suština načina proizvodnje društvenog života se ne mijenja. Centralno pitanje je: na kojoj simetriji počiva ta nepromjenjivost? Bez otkrivanja te simetrije i njene veze sa nepromjenjivošću načina proizvodnje društvenog života, nema objašnjenja društvenog fenomena globalizacije. A to se, može izvesti samo na nivou simetričnosti kvalitativnog posredovanja koje se zasniva na logosnoj valentnosti strukturno-sistemskih elemenata konkretnih društava-država i njihove veze na globalnom nivou. 


\section{UMJESTO ZAKLJUČKA: SIMETRIJSKE MREŽE NACIONALIZMA I GLOBALIZMA}

Suština savremenog svijeta se ne može objasniti bez identifikovanja simetrijskih mreža nacionalizma i globalizma, i njihovog kvalitativnog posredovanja u kojem, posebno značajnu ulogu, ima država. Ovdje je sadržana ključna teorijsko-metodološka hipoteza u sociološkom razumijevanju simetrične refleksivnosti nacionalizma i globalizma u savremenom društvu.

Teorijsko-empirijsko saznanje i iskustvo, potvrđuje hipotezu da autonomnost sile simetrije i asimetrije nacionalizma (pozitivnog ili negativnog) u pojedinim fazama razvitka čovjeka i njegove zajednice, nije mogla negirati bilo koja druga komponenta društvenog razvoja: ekonomska, socijalna, kulturna, politička. "Nema revolucije bez nacionalnog naboja" (Forcades, 2017: 8). Međutim, nacionalizam ne možemo objasniti iz njega samog. Teorijom evolucije "proširene sinteze" sociološki zahvatamo sve bitne okolnosti koje transcendiraju nacionalne okvire i otkrivaju pozitivne i negativne komponente nacionalizma. $U$ tome je nužnost veze nacionalizma $i$ globalizma. Globalizam se ispoljava kao "proširena sinteza" nacionalizma u kojoj se na nov način - simetrijski i asimetrijski - afirmiše generičnost ljudskog roda. $\mathrm{U}$ tom kontekstu treba razumijevati složenost društvenog procesa globalizacije u savremenog društvu. Cjelovitost društvenih kretanja je refleksija protivrečnosti koje bitno utiču na institucionalno struktuiranje savremenog društva. Međutim, nesporna je činjenica da još uvijek globalna društvena kretanja nijesu dovela do nestajanja države ili nacije u savremenom svijetu. Potpuno je neprihvatljivo stanovište da bilo koji globalizacijski procesi dovode do potpunog brisanja nacionalne kulture. Poznato je, da su Jevreji vjekovima u rasejanju po čitavom svijetu, ali njihova nacionalna kultura, ne samo da je dovedena u pitanje, već je danas jača nego bilo kad ranije. Prema tome, sociološko objektivno naučno razumijevanje savremenog svijeta ne može ignorisati ključnu činjenicu realne organizovanosti savremenog svijeta u obliku određenih država i nacija, koje predstavljaju osnovu globalizacijskih procesa. To nije "stara vizija svijeta" kako neki autori tvrde, već ključna činjenica za formiranje savremene vizije svijeta u svim njenim bitnim pojmovnim i kategorijalnim dimenzijama. Bez te vizije ne može se ništa objektivno reći o fenomenu društvenih kretanja. Vizija svijeta bez savremenih država i nacija je prazna vizija, neupotrebljiva za bilo šta ozbiljno u formiranju pogleda na svijet i mjesto čovjeka u svijetu. Perspektiva potpunog brisanja nacionalnih kultura i stvaranje neke jedinstvene svjetske kulture je utopija bez realnih pretpostavki za istorijsko ostvarenje, jer je u sukobu sa ljudskom prirodom i prirodom ljudske zajednice u njihovoj današnjoj esencijalno-egzistencijalnoj postojanosti. Futurološka predviđanja njihove totalne promjene zasnivaju se na budućnosti bez veze sa prošlošću i sadašnjošću 
ljudskog roda, što in čini utopističkim vizijama, koje imaju u vidu samo karakter kapitala, potpuno zapostavljajući karakter ljudi, tj. generičku suštinu čovjeka i njegove zajednice. "Samo neuki, nerazumni ljudi, mogu da smatraju da je prošlost mrtva i neprolaznim zidom odvojena od sadašnjice" (Andrić, 2017: 2). Znači, centralno pitanje je kako otkrivati simetriju transplanetarne povezanosti: globalizma i suštinskih vrijednosti ljudske prirode. To može ići samo na vremensko-prostornoj i kvalitativnoj osnovi organskog vremena (organsko-nelinearno-ciklično vrijeme kao čovjekov neprestani odnos sa: drugim ljudima, prirodom, univerzumom), a ne nikako na kvantitativnoj. Očigledna nužnost spoja univerzalno-konkretno, zasniva se na kvalitativnom posredovanju strukturalnih cjelina svakog konkretnog društva, pri čemu država, kao što smo već konstatovali, ima nezamenljivu ulogu. Kvalitativna diferencijacija, bitno determinisana konstitutivnim i regulatornim karakteristikama pojedinih država, produkuje simetrijske mreže društvenih odnosa na lokalnom i globalnom nivou.

Stvorene simetrijske mreže na ovoj diferencijaciji savremenog društva, globalizacijske i državno-nacionalne imaju progresivni smjer ostvarivanja fundamentalnih ljudskih vrijednosti. Međutim, prate ih i asimetrijske tendencije: a) globalizacijske mreže, sa svojom transdržavnom apstrakcijom, ističu u prvi plan interes kapitala i uskog kruga vlasnika kapitala; državno-nacionalne mreže nemaju cjelovit karakter u obezbeđivanju "ontološke sigurnosti" svojih građana, Suština savremenog svijeta se ne može objasniti bez identifikovanja ovih simetrijskih mreža i njihovog kvalitativnog posredovanja. Na otvorenom putu progresivnog razvitka društva, ka horizontu generičke suštine čovjeka i njegove zajednice, neizbježno stoje nacionalizam i globalizam. Prema tome, dilema nacionalizam ili globalizam, odnosno, nacionalizam protiv globalizma je lažna dilema. Istina se nalazi u kvalitativnom posredovanju nacionalizma i globalizma.

\section{LITERATURA}

Altermatt U [Altermat U] (1997). Etnonacionalizam u Evropi: svjetionik Sarajevo. Sarajevo: Jež.

Andrić I (2017). Razvoj duhovnog života u Bosni pod uticajem turske vladavine. Beograd: Politika.

Arendt H [Arent H] (1991). O revoluciji - odbrana javne slobode. Beograd: Filip Višnjić.

Blagojević - Hjuson M (2017). Srpski identitet u 21 veku / Da li je moguće novo razumevanje zajedništva. Politika, 23. avgusta. http://www.politika.rs/sr/clanak/387441/Pogledi/ Srpski-identitet-u-21-veku-Da-li-je-moguce-novo-razumevanje-zajednistva (23. avgust 2017.) 
Habermas J i Ratzinger J [Habermas J \& Racinger J] (2006). Dijalektika sekularizacije. Beograd: Dosije.

Heidegger M [Hajdeger] (1985). Bitak i vrijeme. Zagreb: Naprijed.

Forcades T [Forkades T] (2017). Nema revolucije bez nacionalnog naboja. Beograd: Politika, 15. april, 8. (štampano izdanje)

Gellner E [Gelner E] (1997). Nacija i nacionalizam. Novi Sad: Matica srpska.

Giddens E [Gidens E] (1998). Posledice modernosti. Beograd: Filip Višnjić.

Kangrga M (2003). Nacionalizam ili demokracija. Zagreb: Razlog.

Karadžić S-V (1957). Život i običaji naroda srpskog. Beograd: Srpska književna zadruga, Kolo, knjiga 340.

Kymlicka W [Kimlika V] (2004). Multikulturalizam. Podgorica: CID.

Kiš D (2016). O nacionalizmu. Tačno.net, 20. novembar. http://www.tacno.net/naslovnica/ danilo-kis-nacionalista-je-strasljivac-i-nikogovickukavica-koja-ne-zeli-da-prizna-svojkukavicluk-2/ (04. mart 2017)

Marx K i Engels F [Marks K \& Engels F] (1968.-1979.). Dela. Beograd: IP Prosveta / IZIRP.

Moser E T [Mozer E-T] (2018). Kako mozak doživljava vreme (intervju s Milicom Momčilović). Politika, 13. oktobar, 3. (štampano izdanje)

Petrović Njegoš P II (1995). Luča mikrokozma. Podgorica: CID.

Piketty T [Piketi T] (2015). Kapital u XXI veku. Novi Sad: Akademska knjiga.

Petrović M (2012). Uvod: Glokalnost transformacije. U: Petrović M (ur.).Glob/kalnost transformacijskih procesa u Srbiji. Beograd: Čigoja štampa, 9 - 14.

Safranski R (2017). Zeit - was sie mit uns macht und was wir aus ihr machen, Frankfurt an Main: Taschenbuh.

Schnapper D [Šnaper D] (1996). Zajednica građana / O modernoj ideji nacije. Sremski Karlovci - Novi Sad: Izdavačka knjižarnica Zorana Stojanovića.

Scholte J-A [Šolte A J] (2009). Globalizacija / kritički uvod. Podgorica: CID.

Vukićević S (2003). Crna Gora na prelazu milenijuma. Cetinje: Centralna narodna biblioteka Republike Crne Gore "Đurđe Crnojević” Cetinje.

Vukićević S (2015). Urbani mega-projekti: destrukcija odnosa društvo-priroda. U: Milenković P, Stojšin S i Pajvančić-Cizelj A (ur.). Društvo prostor. Beograd: Srpsko sociološko društvo / Institut za uporedno pravo / Novi Sad: Filozofski fakultet, 123-137.

Vukićević S (2016a). Njegošu su zahvalni: I Bog i čovjek. Cetinje: Centralna narodna biblioteka Republike Crne Gore "Đurđe Crnojević" Cetinje.

Vukićević, S (2016b). Društveni sistem, institucije, svojina i vlasništvo, građani, preduzetništvo. U: Vukićević S (ur.). Постсоциализм (Черногория - Россия 1990 - 2015). Москва: МГУ имени М.В. Ломоносова - Социологический факультет / Институт социологии и психологии Философский фракультет Университета Черногории, 107-199.

Vukićević S (2016c). Urbani mega-projekti Podgorice i Zagreba u vremenskim i prostornim dimenzijama crnogorskog i hrvatskog društva. U: Svirčić Gotovac A i Šarović R (ur.). Tranzicijska preobrazba glavnih gradova Zagreba i Podgorice kao sustava naselja. Zagreb: Institut za društvena istraživanja u Zagrebu, 25-40.

Zerzan J [Zerzan J] (2012). Future Primitive Revisited. https://archive.org/details/ JohnZerzanFuturePrimitiveRevisited (25. Mart 2017)

Zimbardo Ph [Zimbardo F] (2017). Paradigma vremenskih perspektiva. Politika, 18. decembar, 12. (štampano izdanje) 


\title{
Nationalism and Globalism in a Qualitative Relation
}

\author{
Slobodan VUKIĆEVIĆ \\ Faculty of Philosphy, University of Montegro, Montenegro \\ vukicevic@t-com.me
}

\section{ABSTRACT}

The subject of this paper is the symmetry and asymmetry of nationalism and globalism as a qualitative social relation determined by the logos valences (significance, meaning, and sense) of their structural segments. The aim is to establish symmetrical and asymmetric networks of nationalism and globalism that follow their positive and negative dimensions. Nationalism is, basically, a reflection of the nation that contains all the essential contradictions of the emergence and development of a nation, as well as its historical and metaphysical categorisation. Nationalism as a comprehensive, genetically structured social phenomenon can be socially identified and explained only as a symmetry of its positive and negative components. There is no 'pure' nation in an ideal-type form, which reflects only positive nationalism, and neither is there a nation that reflects only negative nationalism. Reducing nationalism only to its negative side prevents the discovery of its positive side. The reflection of nationalism necessarily takes place in a state where the right of citizenship means acquiring a new, higher level of freedom, constituting the only logic of the nation. Thus, the nation, state, and citizen are inseparable subjects of a certain democratic community. Globalism is not a self-reflection of the global but rather a reflection of identity symmetries of individual societies-states, which encompasses a comprehensive exchange of their fundamental human values and interests. The central question is what qualitative contents maintain the dominant symmetry of globalism and its relation to the (in)variability of the essence of social life generation. The answer to this question is not possible without the identification of symmetric networks of nationalism and globalism and their qualitative mediation, in which the state plays a particularly important role. They contain the original theoretical and methodological approach in the sociological understanding of the symmetrical reflexivity of nationalism and globalism in contemporary society. Only the theoretical and empirical as well as sociological and imaginative discovery of the nature of symmetry and asymmetry of nationalism and globalism can lead to scientifically objective and, at the same time, socially engaged knowledge

Key words: nation, nationalism, globalism, logos valence, reflection, social symmetry, symmetric networks. 
